Discussion Paper No. 08-014

\title{
Assessing Intergenerational Earnings Persistence Among German Workers
}

Philipp Eisenhauer and Friedhelm Pfeiffer

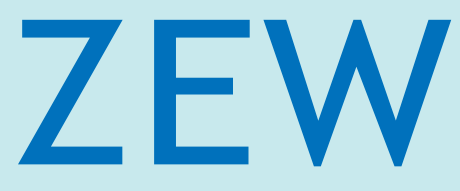

Zentrum für Europäische Wirtschaftsforschung $\mathrm{GmbH}$

Centre for European

Economic Research 
Discussion Paper No. 08-014

\title{
Assessing Intergenerational Earnings Persistence Among German Workers
}

\author{
Philipp Eisenhauer and Friedhelm Pfeiffer
}

Download this ZEW Discussion Paper from our ftp server:

ftp://ftp.zew.de/pub/zew-docs/dp/dp08014.pdf

Die Discussion Papers dienen einer möglichst schnellen Verbreitung von neueren Forschungsarbeiten des ZEW. Die Beiträge liegen in alleiniger Verantwortung der Autoren und stellen nicht notwendigerweise die Meinung des ZEW dar.

Discussion Papers are intended to make results of ZEW research promptly available to other economists in order to encourage discussion and suggestions for revisions. The authors are solely responsible for the contents which do not necessarily represent the opinion of the ZEW. 


\section{Das Wichtigste in Kürze}

Die Vitalität und Stabilität der Demokratie - auch der Wirtschaft hängen letztlich eminent von der Durchlässigkeit der Gesellschaft ab.

(Horst Köhler, Bundespräsident, 29.12.2007)

In dieser Studie wird die Frage der Durchlässigkeit der Gesellschaft, die nach Ansicht des Bundespräsidenten (siehe Eingangszitat) eine wichtige Grundlage der Vitalität und Stabilität der Demokratie ist, empirisch mit repräsentativen Daten von Arbeitnehmern untersucht. Aus ökonomischer Sicht spiegelt sich die Chancengleichheit in einer Gesellschaft unter anderem im Zugang zur Bildung, in der Partizipation am Erwerbsleben und der Höhe des Arbeitsverdienstes wieder. Wir suchen in der vorliegenden Studie Antworten auf die Frage, ob und in welchem Umfang der ökonomische Erfolg am Arbeitsmarkt von der familiären Herkunft abhängig ist.

Datengrundlage sind die monatlichen (realen) Arbeitsverdienste von Vätern und ihren Söhnen aus dem Sozio-ökonomischen Panel, SOEP, 1984 - 2006. Um die intergenerationale Persistenz der Arbeitsverdienste zu schätzen, haben wir eine innovative Stichprobenstrategie entwickelt, die es erlaubt, Vater-Sohn Paare in einem vergleichbaren Abschnitt im Lebenszyklus zu beobachten. Dieser ist so gewählt, dass die Arbeitsverdienste ein Indikator des Lebenseinkommens sind.

Nach den Ergebnissen unserer mikroökonometrischen Schätzungen geht ein Anstieg des väterlichen Arbeitsverdienstes um 10 Prozent mit einer entsprechenden Verbesserung des Sohnes um 3,33 Prozent einher. Am Mittelwert unserer Stichprobe der Söhne berechnet (1.937€), entspricht dies einem um monatlich $63 €$ höheren Arbeitsverdienst.

In der Summe deutet die Analyse darauf hin, dass die intergenerationale Persistenz der Arbeitsverdienste in Deutschland (etwas) höher ist als bisher vermutet. Dennoch weisen die Schätzungen auf eine vergleichsweise hohe intergenerationale Mobilität bezogen auf den Arbeitsmarkt in den letzten beiden Jahrzehnten hin. 


\section{Non-Technical Summary}

The vitality and stability of our democracy - as well as the economy -

eventually depend on the social permeability of our society.

(Horst Köhler, German Federal President, 29.12.2007, own translation)

This statement draws attention to the strong meritocratic believes concerning the equality of opportunity that govern public debates. This is especially true for the education system. But, does this general concern translate into a society in which one's economic success in the labor market is independent of the family born into? And if so, to what degree?

In this study, we investigate intergenerational persistence among German workers. Our measure of labor market success is real monthly earnings before taxes and social security payments. The relationship between fathers' and sons' labor market earnings is assessed with samples drawn from the German Socio-Economic Panel (SOEP) 1984-2006. We introduce a novel sampling procedure that allows us to observe father-son pairs at a rather similar stage of their lifecycle.

From a variety of microeconometric estimates (utilizing both OLS and IV methods) we suggest that the best point estimate of intergenerational earnings persistence among German workers is one-third. Hence, if in the period of investigation a father's permanent labor market earnings increased by 10 percent, the son's long-run economic status grew by 3.33 percent. Evaluated at the mean of our sample of sons $(1,937 €)$, this implies a step up of $63 €$ for the son.

This number indicates a lower degree of mobility (and a higher degree of persistence) in Germany in contrast to preceding studies. In an international perspective, the intergenerational earnings persistence in Germany seems to be lower compared to the United States and higher compared to Sweden. To summarize: there still seems to be substantial intergenerational earnings mobility among German workers, but more persistence than previous research suggested. 


\title{
Assessing Intergenerational Earnings Persistence Among German Workers
}

\author{
Philipp Eisenhauer* Friedhelm Pfeiffer ${ }^{\dagger}$
}

This version: March 17, 2008

\begin{abstract}
In this study we assess the relationship between father and son earnings among (West) German Workers. To reduce the lifecycle and attenuation bias a novel sampling procedure is developed and applied to the German Socio-Economic Panel (SOEP) 1984-2006. Our preferred point estimate indicates that about $\frac{1}{3}$ of the earnings differential in the labor market has been passed on from the generation of fathers to their sons.
\end{abstract}

Keywords: Intergenerational Mobility, Lifecycle, Permanent Earnings, Wages JEL-Classification: J62, J31, J21

\begin{abstract}
Acknowledgements: We thank the Leibniz Association for financial support from the research network "Noncognitive Skills: Acquisition and Economic Consequences". Furthermore Friedhelm Pfeiffer acknowledges financial support from the German Research Foundation under grants PF 331/2-4 ("Microeconometric Methods to Assess Heterogeneous Returns to Education"). For helpful discussions we thank Johannes Gernandt, Maresa Sprietsma, Thorsten Vogel, participants of the 7th meeting of the DFG Workshop "Flexibility in Heterogeneous Labour Markets" on the 4th of October 2007 in Nuremberg, and our colleagues at the ZEW. We thank Alina Botezat and Moritz Meyer for their fine research assistance. All remaining errors are our own.
\end{abstract}

\footnotetext{
${ }^{*}$ Centre for European Economic Research and Graduate School of Economic and Social Sciences, University of Mannheim. Corresponding author: peisenha@rumms.uni-mannheim.de.

${ }^{\dagger}$ Centre for European Economic Research and University of Mannheim
} 


\section{Introduction and Motivation}

The vitality and stability of our democracy - as well as the economy eventually depend on the social permeability of our society $\left.\right|^{1}$

This statement draws attention to the strong meritocratic believes concerning the equality of opportunity that govern public debates. This is especially true for the education system. According to public rhetoric it is aimed to guarantee social mobility in Germany. Families receive a child benefit transfer, schooling for up to 13 years is free of charge and, if education is continued at a university, the cost of living is covered by federal aid for students from low-income families. But, does this general concern translate into a society in which one's economic success is independent of the family born into? And if so, to what degree?

To empirically analyze the intergenerational relationship, the following econometric model

$$
y_{1}^{i}=\alpha+\beta_{y} y_{0}^{i}+\epsilon_{1}^{i}
$$

is used as a starting point (Corak 2004). A linear relationship between long-run economic status $\left(y_{0,1}^{i}\right)$ of family $i$ in generation 0 and 1 is assumed, allowing for shifts in mean economic status independent of parental status via the parameter $\alpha$. Deviations from predicted status due to market luck or other random elements in the intergenerational transmission of skills and personal traits are summarized in the idiosyncratic error term $\epsilon_{1}^{i}$. Ideally, permanent earnings are chosen as the measure of economic status (Friedman 1957). We use both terms to describe the long-run economic success of an individual. In the case all status variables are measured in their natural logarithm, $\beta_{y}$ in equation (1) is the intergenerational elasticity of permanent earnings. It measures the (expected) percentage change in offspring's economic status associated with a one percent change in parental success. A positive value does indicate generational persistence of permanent earnings in which higher parental long-run status favors economic success of one's offspring; a negative number indicates generational reversal of economic status. A value of zero for the intergenerational elasticity $\beta_{y}$ (child's and parental economic success are uncorre-

\footnotetext{
${ }^{1}$ Horst Köhler, German Federal President, in an interview with the Frankfurter Allgemeine Zeitung, 29.12.2007, Berlin (own translation).
} 
lated) corresponds to complete intergenerational mobility, while a value of unity (the child's economic success is completely determined by parental achievement) is associated with complete immobility. $\left(1-\beta_{y}\right)$ provides a measure of the degree to which economic status regresses to the mean (Becker \& Tomes 1986, Goldberger 1989). If it takes value one $\left(\beta_{y}=0\right)$, a child from parents who attain below average long-run status can expect average status just as the offspring of high-status parents.

Although there is agreement about the existence of an intergenerational link in economic status, a number of recent studies debate its varying magnitude across countries (Solon 2002, Grawe 2006, Jäntti, Røed, Naylor, Björklund, Bratsberg, Raaum, Österbacka \& Erikson 2006). While many features of the human skill formation process are universal, there may however be unique features in German data. In an international perspective, low tuition fees and federal student aid might ease the impact of borrowing constraints and thus enhance mobility in Germany compared to other countries (Mulligan 1997).

The contribution of our paper to the literature on intergenerational persistence is twofold. First, recent improvements in the understanding of the association between short- and long-run economic status allow for a new assessment of potential biases in previous studies. Deviations of current from permanent economic status arise due to transitory fluctuations (Bowles 1972, Solon 1992) and a time-varying association between the two (Haider \& Solon 2006, Grawe 2006). We introduce a novel sampling procedure that accounts for both and allows to observe father-son pairs at a rather similar stage of their lifecycle. Second, the relationship is assessed for Germany with samples drawn from the German Socio-Economic Panel (SOEP) 1984-2006.

Our results suggest that the best point estimate of intergenerational earnings persistence among West German workers is $\frac{1}{3}$. This indicates a lower degree of mobility (and a higher degree of persistence) in Germany compared to Couch \& Dunn (1997) and Wiegand (1997) but is in line with Vogel (2007), who compares intergenerational mobility between Germany and the United States. In an international perspective, the intergenerational earnings persistence seems to be lower compared to the United States $\beta_{y}^{U S}=0.4$ (Solon 1992), and higher compared to Sweden $\beta_{y}^{S}=0.2$ (Björklund \& Jäntti 1997). There still seems to be substantial intergenerational earnings mobility among West German workers, but more persistence than previous research suggested.

The remainder of this paper is organized as follows: Section 2 provides an introduction to the econometric methods applied to estimate intergenerational persistence 
with incomplete data. Section 3 presents our novel sampling procedure with the SOEP. Section 4 discusses the econometric findings, whereas Section 5 concludes.

\section{Econometric Problems and Findings from the Literature}

In this section the econometric problems associated with measuring intergenerational persistence and the consequences we draw regarding its estimation among German workers are pointed out.

\subsection{Measurement Error Problems}

The deduction of an individual's permanent earnings requires a life-long earnings history. Since researchers usually lack direct measures of long-run status $y_{0,1}^{i}$ for two generations in order to investigate intergenerational mobility, they rely on proxies $\left(y_{0 h}^{i}, y_{1 t}^{i}\right)$ of permanent earnings for each generation $(0,1)$ observed at age $h$ and $t$. Sometimes only single-year measures of earning $\$^{2}$ have been used. Usually, however, a short-run measure of economic status is an imperfect proxy of long-run status. It is subject to measurement error due to transitory fluctuations and lifecycle variation in the association between current and lifetime earning $\$ 3$.

\subsubsection{Transitory Fluctuations}

Current earnings of fathers $y_{0 h}^{i}$ and sons $y_{1 t}^{i}$ can be decomposed as follows (Friedman 1957).

$$
\begin{aligned}
& y_{1 t}^{i}=y_{1}^{i}+v_{1 t}^{i} \\
& y_{0 h}^{i}=y_{0}^{i}+v_{0 h}^{i}
\end{aligned}
$$

$y_{0,1}^{i}$ describe time-invariant permanent earnings, while $\left(v_{0 h}^{i}, v_{1 t}^{i}\right)$ indicates timevarying transitory fluctuations. The latter might arise from job mobility, business cycle effects or variable compensation schemes. If current earnings deviate from permanent status, using them as a proxy for long-run status introduces attenuation bias in the estimation of equation (1). Assuming that $v_{1 t}^{i}$ and $v_{0 h}^{i}$ are uncorrelated

\footnotetext{
${ }^{2}$ See Behrman \& Taubman (1985) as an example.

${ }^{3}$ For a further errors-in-reporting problem see Bound \& Krueger (1991) and Duncan \& Hill (1985).
} 
with each other and permanent earnings $y_{0,1}^{i}$, a deviation implies a downward inconsistency of the estimated slope coefficient $\hat{\beta}_{y}^{O L S}$ in an OLS estimation by the factor $\theta_{h}$ (Solon 1992).

$$
\begin{aligned}
\operatorname{plim} \hat{\beta}_{y}^{O L S} & =\theta_{h} \beta_{y}<\beta_{y} \\
\theta_{h} & =\left(\frac{\operatorname{Var}\left[y_{0}\right]}{\operatorname{Var}\left[y_{0}\right]+\operatorname{Var}\left[v_{0 h}\right]}\right)
\end{aligned}
$$

The attenuation factor $\theta_{h}$ captures how much signal $\operatorname{Var}\left[y_{0}\right]$ is provided by the measure $y_{0 h}$ relative to its total noise, $\operatorname{Var}\left[y_{0 h}\right]=\operatorname{Var}\left[y_{0}\right]+\operatorname{Var}\left[v_{0 h}\right]$.

Based on single-year snapshots, empirical findings by Corcoran, Laren, Gordon \& Solon (1991), Card (1994) and Hyslop (2001) suggest an attenuation factor around $\theta_{h}=0.5$. This implies a (considerable) signal-to-noise ratio of observed parental earnings and an attenuation bias of $\left(1-\theta_{h}\right)=0.5$. Note also, that transitory fluctuations in offspring's earnings $v_{1 t}^{i}$ do not bias the OLS estimation in equation (1) as long as they are uncorrelated with $v_{0 h}^{i}$. However, the higher their variance, the larger the confidence interval of $\hat{\beta}_{y}^{O L S}$ will be.

\section{Averaging Parental Earnings}

To decrease the magnitude of the inconsistency, Solon (1992) suggests to average parental status over $T$ years which reduces the variance of the noise relative to the signal. Transitory shocks are averaged away, as long as the process is stationary, see Mazumder (2005).

$$
\theta_{h}=\left(\frac{\operatorname{Var}\left[y_{0}\right]}{\operatorname{Var}\left[y_{0}\right]+\frac{1}{T} \operatorname{Var}\left[v_{0 h}\right]}\right)
$$

As more years of data are used, the attenuation factor $\theta_{h}$ rises and the attenuation bias $\left(1-\theta_{h}\right)$ declines. According to Mazumder (2005), the attenuation factor $\theta_{h}$ rises to $\theta_{h}=0.7$ (from $\theta_{h}=0.5$ ) when relying on a 5-year average of earnings. The attenuation bias is reduced to $\left[\left(1-\theta_{h}\right)=0.3\right]$. Solon (1992) and Wiegand (1997) estimated an intergenerational elasticity of father's and son's earnings based on 5-year averages of 0.4 for the United States and 0.2 for Germany. Given the attenuation factor mentioned above the "true" elasticities would come closer to 0.6 for the United States and 0.3 for Germany. 
In a second approach, Solon (1992) assumes that offspring's permanent earnings $y_{1}^{i}$ are not solely determined by parental long-run status $y_{0}^{i}$ as in equation (1), but by an additional factor $I_{0}^{i}$ as well.

$$
y_{1}^{i}=\beta_{1} y_{0}^{i}+\beta_{I} I_{0}^{i}+\omega_{1}^{i}
$$

In this case, the direct projection of offspring's permanent earnings on parental long-run status introduces an omitted-variable bias.

$$
\begin{aligned}
& y_{1}^{i}=\beta_{y} y_{0}^{i}+\epsilon_{1}^{i} \\
& \beta_{y}=\beta_{1}+\beta_{I}\left(\frac{\operatorname{Cov}\left[I_{0}, y_{0}\right]}{\operatorname{Var}\left[y_{0}\right]}\right)
\end{aligned}
$$

An instrumental variable estimation, with $I_{0}^{i}$ as the instrument will have the following probability limit, Solon (1992).

$$
\begin{aligned}
\operatorname{plim} \hat{\beta}_{y}^{I V} & =\beta_{y}+\beta_{I}\left(\frac{1-\kappa^{2}}{\kappa}\right)\left(\frac{S d\left[I_{0}\right]}{S d\left[y_{0}\right]}\right) \\
\kappa & =\frac{\operatorname{Cov}\left[I_{0}, y_{0}\right]}{S d\left[y_{0}\right] S d\left[I_{0}\right]}
\end{aligned}
$$

$\hat{\beta}_{y}^{I V}$ is an unbiased estimator for $\beta_{y}$ only if the instrument does not influence offspring's status $\left(\beta_{I}=0\right)$ or the instrument and parental status are perfectly correlated, $|\kappa|=1$. The closer $|\kappa|$ is to one, the smaller the bias as there is less variation in earnings that is not captured by the instrument. Assuming a positive but imperfect correlation between the instrument and parental long-run status, the direction of the inconsistency is determined by $\beta_{I}$. If the instrument $I_{0}^{i}$ has a positive impact on offspring' s status $\left(\beta_{I}>0\right)$, the estimator will be biased upward. If the opposite is true, the estimated coefficient is downward biased like the OLS estimate.

In empirical research, parental years of education (Solon 1992, Dearden, Machin \& Reed 1997) or indicators of occupational prestige (Zimmerman 1992, Wiegand 1997) have been used to instrument long-run parental status. Since years of education enhance labor market earnings, it may capture an important part of parental per- 
manent earnings, although not necessarily to a $100 \%$. In this case an IV estimate using years of education will be upward biased.

Estimating the intergenerational elasticity $\hat{\beta}_{y}$ using OLS and IV techniques therefore suggests to bracket the coefficient (Solon 1992). The OLS estimate is downward inconsistent due to error-in-variable bias, whereas the IV estimate is presumably upward biased. Accounting for the associated standard errors, $\beta_{y}$ is located between the two estimates.

$$
\hat{\beta}_{y}^{O L S}<\beta_{y}<\hat{\beta}_{y}^{I V}
$$

\subsubsection{Lifecycle Variations}

Empirical research as well as theoretical reasoning suggest that wage workers differ with respect to their age-earnings profiles 5 . This may occur due to age-specific heterogeneity in human capital investment or variations in the wage structure across jobs erected by firms for the purpose of effort regulation and incentive compatibility. For estimation purposes, the projection of current on permanent earnings is generalized to include a time-varying parameter $\lambda_{t, h}$ to capture age-specific aspects in the association between current and permanent earnings over the lifecycle (Haider \& Solon 2006).

$$
\begin{aligned}
y_{1 t}^{i} & =\lambda_{t} y_{1}^{i}+v_{1 t}^{i} \\
y_{0 h}^{i} & =\lambda_{h} y_{0}^{i}+v_{0 h}^{i}
\end{aligned}
$$

Averaging parental earnings $y_{0 h}^{i}$ across $T$ years, the interaction of both types of measurement error is considered. If parental and offspring's long-run status is proxied by short-run earnings, equation 14 determines the potential bias.

$$
\begin{aligned}
\operatorname{plim} \hat{\beta}_{y}^{O L S} & =\lambda_{t} \theta_{h} \beta_{y} \\
\theta_{h} & =\frac{\lambda_{h} \operatorname{Var}\left[y_{0}\right]}{\lambda_{h}^{2} \operatorname{Var}\left[y_{0}\right]+\frac{1}{T} \operatorname{Var}\left[v_{0 h}\right]}
\end{aligned}
$$

\footnotetext{
${ }^{4}$ See Card (1999) for a recent survey.

${ }^{5}$ See Mincer (1975) and Baker (1997) among others and Vogel (2007) for an application to intergenerational mobility.
} 


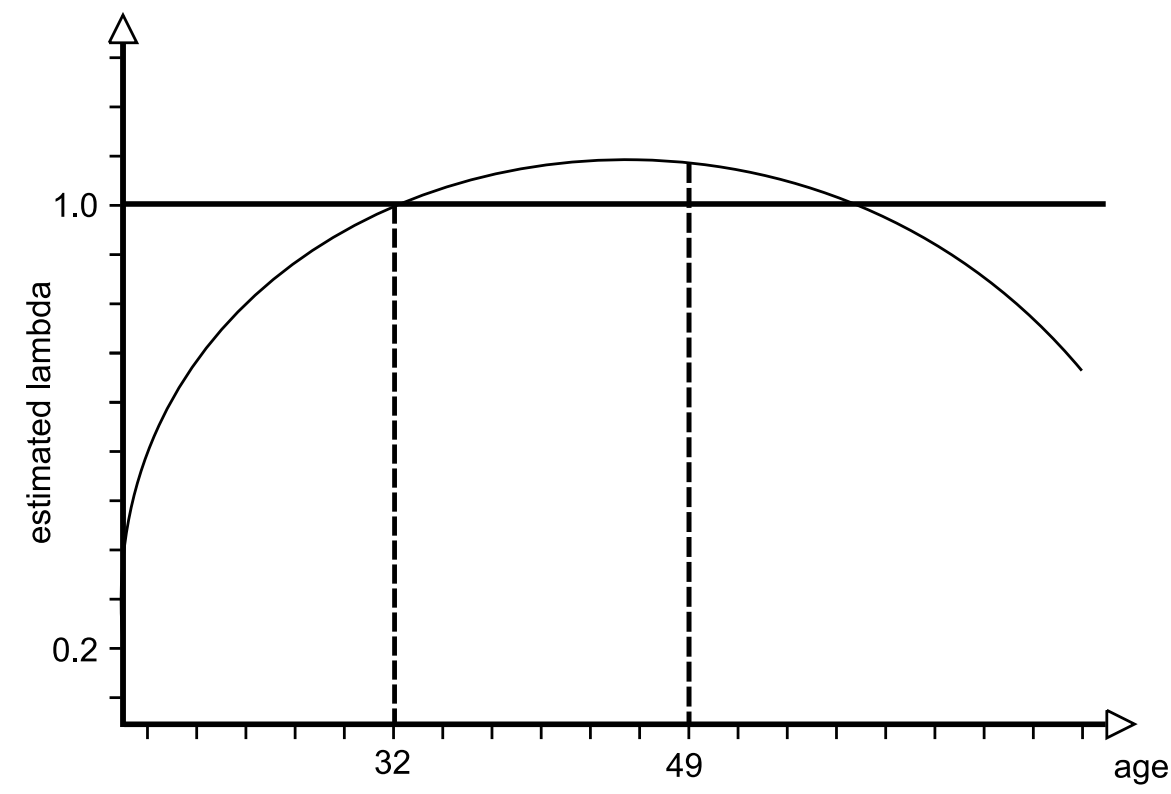

Figure 1: Estimated Correlation Between Current and Permanent Earnings

Assuming $\theta_{h}=1$, the probability limit of the estimated coefficient $\hat{\beta}_{y}^{O L S}$ is $\lambda_{t} \beta_{y}$ instead of $\beta_{y}$. In the case of $\lambda_{t}=1$ (as implicitly assumed in the discussion of transitory fluctuations) this does no harm, but in general, the estimator will be inconsistent and the inconsistency varies as a function of age $t$ at which earnings are observed. Focusing on the impact of $\theta_{h}$ (setting $\lambda_{t}=1$ ), it is not obvious whether the combination of transitory fluctuations and lifecycle variation leads to an amplification bias instead of an attenuation bias. For $\lambda_{h}>1$ the estimation is downward biased, but for values smaller than one and minor transitory variance the opposite is true. $\theta_{h}$ is a summary measure of the attenuation bias resulting from transitory fluctuations as well as lifecycle variation. Therefore the age-composition of the sample matters (Jenkins 1987, Grawe 2006). In summary, measurement error in offspring's status is not innocuous for consistency as well as measurement error in parental long-runs status. Both induce either amplification or attenuation bias of the OLS estimation.

Using U.S. Social Security Administration earnings histories of members of the Health and Retirement Study sample, Haider \& Solon (2006) asses the magnitude of measurement error in offspring's and parental permanent earnings separately. Their dataset ranges from 1951 to 1991 and provides nearly career-long earnings histories 


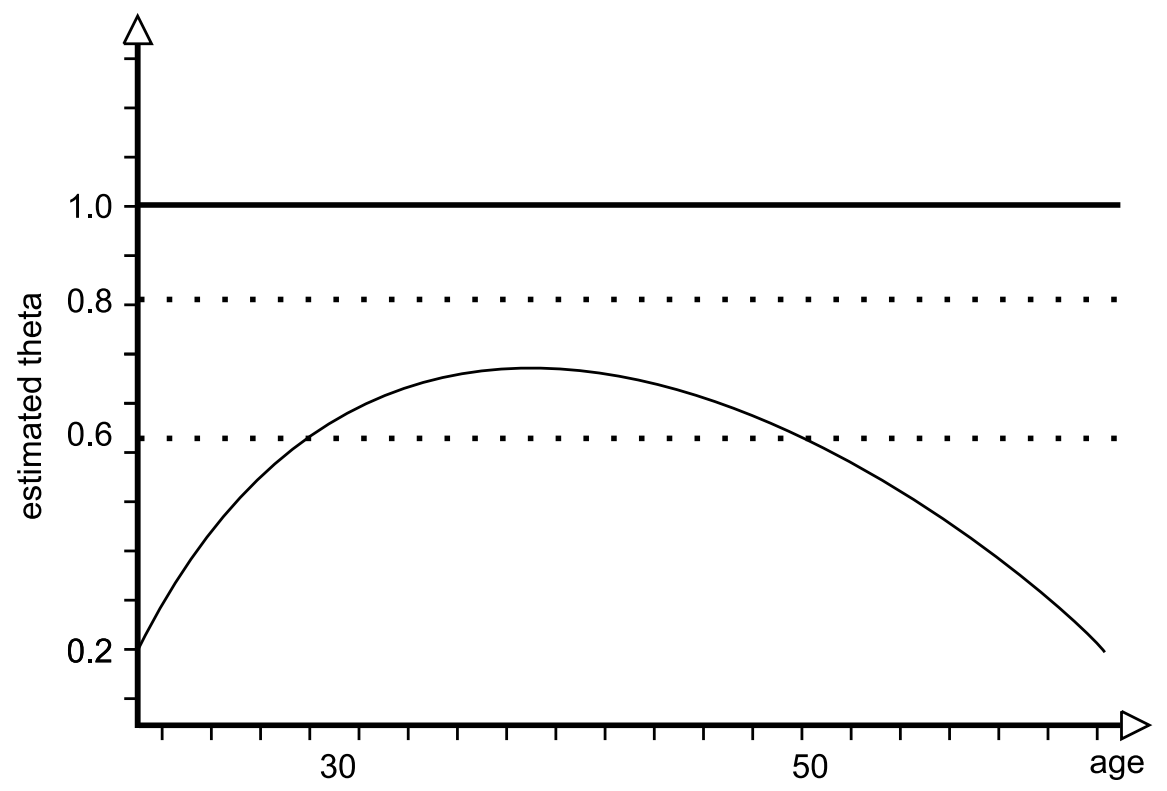

Figure 2: Estimated Reliability Ratio

for a broadly representative sample of the U.S. population. This allows to derive a more precise estimate of the (logarithmized) present value of lifetime earnings $\ln V^{i}$. Starting with the impact of measurement error in offspring's (permanent) earnings level, the forward regression of $\ln V^{i}$ on $y_{t, h}^{i}$ leads to the estimated slope coefficient $\hat{\lambda}_{t, h}$ depicted in figure 1. Starting at a value around $\hat{\lambda}_{t, h}=0.2$ it increases steadily. At age 32, the textbook assumption of $\lambda_{t, h}=1$ seems reasonable. Thenceforward, $\hat{\lambda}_{t, h}$ declines some in the late forties. Turning to the case of measurement error in parental permanent earnings, the estimated reliability ratio $\hat{\theta}_{h}$ is depicted in figure 2. It is the result of a backward regression of $\ln V^{i}$ on a 5 -year average of $y_{t, h}^{i}$. A significant increase till age 30 is followed by a quite robust factor between 0.6 and 0.8 , but after the age of $50, \hat{\theta}_{h}$ declines and the bias rises. Unfortunately, we are not aware of any comparable work for the case of Germany.

\subsection{Sample Homogeneity}

In selected sub-populations with respect to location, socioeconomic status or occupation, the sample variance in long-run economic status is possibly less than in the whole population. For example, a study by Sewell \& Hauser (1975) was based on a selective son-sample from Wisconsin, who graduated in 1957 and thus 
excluded high-school dropouts, leaving only rather successful sons in the sample. Similarly, Behrman \& Taubman (1985) are confined to parental data on white male twins born between 1927 and 1929, who both served in the Army. Presumably, this father-sample is rather homogeneous. Both types of selectivity may introduce a third source of inconsistency as Solon (1989) points out. To concentrate on the effect of sample homogeneity, long-run status is assumed to be measured correctly until indicated otherwise. Formally speaking, the parental/offspring-sample is more homogeneous in long-run status, if the variance in permanent earnings $\operatorname{Var}\left[y_{j=0,1}^{*}\right]$ is only a fraction $\tau$ of the population variance $\operatorname{Var}\left[y_{j=0,1}\right]$.

$$
\operatorname{Var}\left[y_{j=0,1}^{*}\right]=\tau \operatorname{Var}\left[y_{j=0,1}\right]
$$

Under normality of parental economic status, selection on the dependent variable leads to a proportional change in the estimated intergenerational elasticity, where $R^{2}$ is the coefficient of determination of the population-based regression model (Goldberger 1981).

$$
\begin{aligned}
\operatorname{plim} \hat{\beta}_{y *}^{O L S} & =\phi \beta_{y}<\beta_{y} \\
\phi & =\frac{\tau}{1-R^{2}(1-\tau)}
\end{aligned}
$$

If $\tau<1$ (implying $\phi<1$ ) the estimated intergenerational elasticity $\hat{\beta}_{y *}^{O L S}$ is downward inconsistent even though long-run status is measured correctly.

A sample exhibiting homogeneity in parental earnings does not affect the consistency of intergenerational elasticity estimates. This is true as long as economic status is measured correctly. If this is not the case, the downward bias is worsened (Solon 1992, Wiegand 1997), see equation (19).

$$
\begin{aligned}
&\left(\frac{\operatorname{Var}\left[y_{0 *}\right]}{\operatorname{Var}\left[y_{0 *}\right]+\operatorname{Var}\left[v_{0 h}\right]}\right) \beta_{y}= \operatorname{plim} \hat{\beta}_{y *}^{O L S}< \\
& \operatorname{plim} \hat{\beta}_{y}^{O L S}=\left(\frac{\operatorname{Var}\left[y_{0}\right]}{\operatorname{Var}\left[y_{0}\right]+\operatorname{Var}\left[v_{0 h}\right]}\right) \beta_{y}
\end{aligned}
$$

In applied empirical research, inclusion into an intergenerational dataset requires for father and son to both report positive labor market earnings in the periods of interest. Presumably, in such samples $\beta_{y}$ is underestimated, but the use of larger representative samples eases this problem. To the best of our knowledge, however, there is no research on the magnitude of this bias available. 


\section{Econometric Approach and Sampling Procedure}

We estimate the following econometric model presented in equation 201. Son's observed status $y_{1 t}^{i}$ in year $t$ is expressed as a regression function of father's observed status $y_{0 h}^{i}$ in year $h$, including age-controls for both (Solon 1992, Zimmerman 1992, Wiegand 1997, Vogel 2007). It is derived by the incorporation of age-earnings profiles into equations (2) and (3) and substitution into the basic equation (1).

$$
y_{1 t}^{i}=\beta_{0}+\beta_{y} y_{0 h}^{i}+\beta_{1} A_{0 h}^{i}+\beta_{2} A_{0 h}^{2 i}+\beta_{3} A_{1 t}^{i}+\beta_{4} A_{1 t}^{2 i}+\omega_{1 t}^{i}
$$

An individual's current earnings are determined by the level of permanent earnings $\left(y_{1}^{i}, y_{0}^{i}\right)$ the stage in the lifecycle $\left[\left(A_{t}^{i} ; A_{t}^{2 i}\right),\left(A_{h}^{i} ; A_{h}^{2 i}\right)\right]$, a general level of economic well-being in the corresponding generation $\left(\alpha_{1}, \alpha_{0}\right)$, and an idiosyncratic error term $\left(v_{1 t}^{i}, v_{0 h}^{i}\right)$.

$$
\begin{aligned}
& y_{1 t}^{i}=y_{1}^{i}+\alpha_{1}+\gamma_{1} A_{1 t}^{i}+\delta_{1} A_{1 t}^{2 i}+v_{1 t}^{i} \\
& y_{0 h}^{i}=y_{0}^{i}+\alpha_{0}+\gamma_{0} A_{0 h}^{i}+\delta_{0} A_{0 h}^{2 i}+v_{0 h}^{i}
\end{aligned}
$$

The empirical part builds on samples form the German Socio-Economic Pane 6 (SOEP) from 1984 to 2006. To assure comparability of real earnings observed in different years, they are adjusted by the real GDP-Growth Rate. Our measure of long-run economic status are rea $7^{7}$ monthly earnings before tax and social security deductions as reported in each cross-section of the $\mathrm{SOEP}^{8}$. This allows for international comparison! Measuring all earnings variables in their natural logarithm, we choose the intergenerational earnings elasticity as our indicator for intergenerational mobility and use both terms interchangeably. Thus, our indicator is a summary measure of personal characteristics shared by parent and offspring that are valued

\footnotetext{
${ }^{6}$ Consult Haisken-DeNew \& Frick (2005) for further information on the dataset.

${ }^{7}$ Deflated by the consumer price index (base year 2000) supplied by the German Federal Statistical Office.

${ }^{8}$ This approach is similar to Wiegand (1997), but different from Vogel (2007), who calculates a measure of yearly earnings from monthly earnings records.

${ }^{9}$ See Solon (1999) for a survey on intergenerational earnings mobility. We concentrate on persistence of labor market earnings. For research using a more inclusive measure of total economic status made up by a variety of differing types of income, earnings and monetary inheritance see Piketty (2000) and Mulligan (1997) among others. It is left for future research to construct a more inclusive measure with the SOEP, since sample size is reduced and the problem of measurement error increases.
} 
in the German labor market. This includes similarities in educational attainment and cognitive performance, but also noncognitive skills and personal traits seem to play an important role as well (Bowles, Gintis \& Osborne-Groves 2001, Bowles \& Gintis 2002).

Table 1: Final Sample Overview

\begin{tabular}{|c|c|c|}
\hline \hline Groups Excluded from Sample & Measures of Economic Status & Age - Restrictions \\
\hline self-employed & $\underline{\text { Son }}$ & \\
part-time employed & monthly earnings $(1984-2006)$ & between $30-50$ \\
East Germans & $\underline{\text { Father }}$ & \\
migrants & monthly earnings $(1984-2006)$ & \\
younger brothers & years of education & \\
\hline \hline
\end{tabular}

A novel feature of our study is the sampling procedure. We select pairs of fathers and sons in a way that their earnings are observed as close in their lifecycle as possible. Furthermore, the bias due to transitory fluctuations and lifecycle variation is minimized, see table1. As a start, the self-employed, who have more volatile earnings (Baker \& Solon 2003, Albarrán, Carrasco \& Martínez-Granado 2007, Pfeiffer 1994) are excluded. Only full-time employed are retained in the sample, that is individuals reporting to work more than 35 hours the last week. Workers from East Germany are excluded as well since the possibility for mobility increased dramatically after the fall of the Berlin Wall and drastic wage growth 10 may have changed the reliability of current earnings to reflect permanent status. Migrants are dropped from the analysis for two reasons. First, migration might change the long-run relationship between labor market earnings of father and son, and, second, the transitory component is presumably relatively high which increases the attenuation bias (Borjas 2006, Friedberg 2000). To avoid sample homogeneity, only the oldest sibling is included in our baseline specification (Solon 1992). For the group of fathers, moving 5-year averages of earnings and age are calculated to reduce the attenuation bias. Thus, if for a given observation earnings are not observable in each of the four following years, it is dropped.

Furthermore, the following age restrictions are imposed (and relaxed again for further discussion) to account for the time-varying association between short- and

\footnotetext{
${ }^{10}$ See Hunt (2002) among others.
} 
long-run economic status. This procedure accounts for the pattern of the variance of the transitory component over the lifecycle (which flattens out at mid age in the U.S. (Baker \& Solon 2003)). Since the association between monthly and lifetime earnings is still low for workers below the age of 30, we select workers above that age. For younger workers job mobility is high and earnings are more volatile, partly because of lower tenure (Haider \& Solon 2006, Björklund 1993). Workers aged above 50 years are excluded as well. Labor market status and hours worked may become more volatile again which might depress the estimated level of persistence (Grawe 2006). However, this line of reasoning may differ between countries, for instance as a result of different industrial structures or different degrees of employment protection laws (Blau \& Kahn 1996, OECD 1999, Pries \& Rogerson 2005).

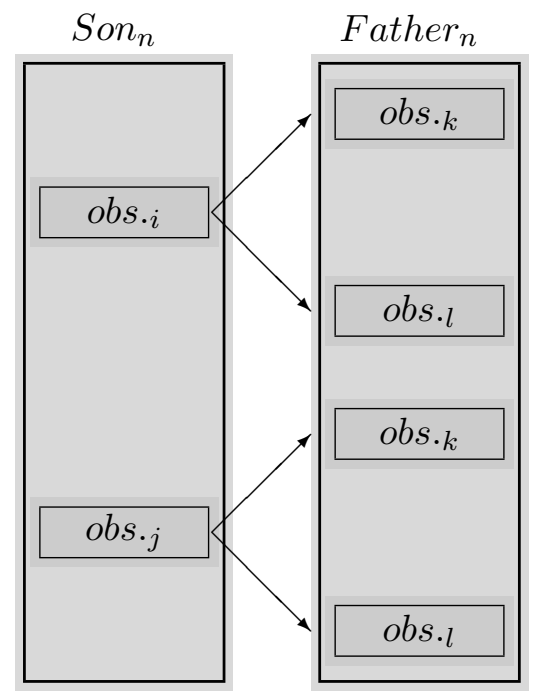

Figure 3: Sampling Strategy

Finally, father $\left(o b s_{k}\right.$ and $\left.o b s_{l}\right)$ and son $\left(o b s_{j}\right.$ and $o b s_{i}$ ) observations (of family $n$ ) satisfying the sampling rule are matched in all possible combinations, see figure 3 . This procedure leads to numerous matched observations for each father-son pair. To identify a unique pair, intended to lead to the most reliable estimate of the intergenerational elasticity, a decision rule is implemented. For each observation we select the one with the smallest absolute age-difference between father and son. This is to ensure that father and son are observed at as similar stages in their lifecycle as possible. If still more than one observation for a particular father-son pair fulfills the requirement, the one associated with the lowest father age is used. For comparison 
and discussion, other samples with less restrictive selection rules are utilized in the next section.

The sample contains 180 father-son pairs compared to Wiegand's (1997) 130 and Vogel's (2007) 300. Table 2 depicts the basic statistics. The age-difference between father and son amounts to 8.68 years. Sons in the sample report less earnings than their matched fathers which is mainly explained by their early stage in the lifecycle. While most information on father's economic status is obtained within the early SOEP waves, the collection of offsprings' information is not confined to the most recent wave. The age-composition of our sample differs substantially from previous works. Sons are 35 years old which is an increase of 4 years compared to Wiegand (1997) and 13 years compared to Couch \& Dunn (1997). Solon (1992) reports an average age of 29 for sons, while Björklund \& Jäntti (1997) rely on sons at the age of 34 on average. An average age of 44 years for fathers is slightly lower than the one reported by Wiegand (1997) with 46 years, while Couch \& Dunn's (1997) fathers are 51 years old. Solon's (1992) fathers are reported to be 42 years of age on average, nearly identical to an average father in Björklund \& Jäntti's (1997) sample (43 years).

Table 2: Final Sample Statistics

\begin{tabular}{|l|r|r|}
\hline \hline \multicolumn{1}{|c|}{ Statistic } & \multicolumn{1}{|c|}{ Fathers } & \multicolumn{1}{c|}{ Sons } \\
\hline Gross Earnings in $€^{1}$ & $2,307.03$ & $1,936.87$ \\
Sd. of Gross Earnings & 716.82 & 640.40 \\
Year of Observation & 1,987 & 2,004 \\
Age in Years & 44.40 & 35.73 \\
\cline { 2 - 3 } Age - Difference in Years & \multicolumn{2}{|c|}{8.68} \\
\hline Number of Observations & \multicolumn{2}{|c|}{} \\
\hline \hline
\end{tabular}

Selection could rise from the blind eye on individuals not meeting the selection rules, table 2. The final sample is compared to all workers living up to the sample requirements except for the need to report positive earnings 5 years in a row and being matched with their offspring. The father-sample is contrasted in 1984, while the son-sample is compared in 2004. Earnings in the father-sample are nearly identical to the one reported by all workers in $1984(2,331.01 €)$. However, the standard deviation is higher in the comparison group (782.43€) in 1984. Using 5-year averages of 
earnings in the father-sample, therefore, as intended, reduces transitory fluctuations. Comparing the son-sample, earnings are higher (1,917.13€in the comparison group) and show a higher standard deviation $(574.15 €)$. In our son-sample the average age is lower which induces higher wage dispersion.

\section{Econometric Findings}

\subsection{Basic Results}

Table 3: Basic Results

\begin{tabular}{|c|c|c|}
\hline & 5 - Year Avg. Earnings & Single - Year Earnings \\
\hline \multicolumn{3}{|l|}{ OLS - Estimate } \\
\hline Intergenerational Elasticity & 0.282 & 0.205 \\
\hline $95 \%$ Confidence Interval & $(0.09-0.44)$ & $(0.08-0.32)$ \\
\hline Standard Error & 0.087 & 0.061 \\
\hline Observations & 180 & 249 \\
\hline \multicolumn{3}{|l|}{$\underline{\text { IV - Estimate }}^{1}$} \\
\hline Intergenerational Elasticity & \multicolumn{2}{|c|}{0.374} \\
\hline 95\% Confidence Interval & \multicolumn{2}{|c|}{$(0.09-0.65)$} \\
\hline Standard Error & \multicolumn{2}{|c|}{0.144} \\
\hline Observations & \multicolumn{2}{|c|}{180} \\
\hline
\end{tabular}

${ }^{1}$ using years of education

The OLS estimate based on a 5 -year average of earnings $\hat{\beta}_{y}^{O L S}=0.282$ is higher compared to Wiegand (1997), whereas the one-year snapshot is about the same, table 3 . Compared to Vogel (2007), the result based on the 5-year average of earnings is similar. We use years of education ${ }^{11}$ as an instrument to bracket the intergenerational elasticity. According to the IV estimate the intergenerational elasticity is higher, $\hat{\beta}_{y}^{I V}=0.374$. Following Solon's (1992) approach, the intergenerational

\footnotetext{
${ }^{11}$ This variable includes both, school and occupational education. The German school system introduces differentiated educational tracks after four grades of primary education. The basic school (Hauptschule) graduates individuals after five years of secondary education and is traditionally a preparation for blue collar occupations. The middle school (Realschule) lasts six years and trains for white collar employment. The highest track (Gymnasium) offers nine years of schooling and a degree (Abitur), which is a precondition for academic studies. Completion of an apprenticeship adds another 1.5 years, a technical college 3 years, and graduation form university increases years of education by 5 years.
} 
elasticity of German Workers should lie between the two estimates and we suggest a reasonable value of $\frac{1}{3}$.

$$
\hat{\beta}_{y}^{O L S}=0.282<\beta_{y}<0.374=\hat{\beta}_{y}^{I V}
$$

The $95 \%$ confidence interval of the IV estimate $\left[0.09 \leq \hat{\beta}_{y}^{I V} \leq 0.66\right]$ includes the OLS estimate. Although the two point estimates contain some useful information, the degree of precision seems to be rather low. We come back to this issue in the conclusion.

\subsection{Investigating the Bias from Transitory Fluctuations}

Table 4: Summary Results ${ }^{1}$ : Balanced Panel

\begin{tabular}{|l|l|l|l|l|l|}
\hline \hline Father Measure $^{2}$ & $5-$ Year & $4-$ Year & 3 - Year & 2 - Year & 1 - Year \\
\hline Intergenerational Elasticity & $0.2822^{* * *}$ & $0.2841^{* * *}$ & $0.2751^{* * *}$ & $0.2441^{* * *}$ & $0.1984^{* *}$ \\
$95 \%$ Confidence Interval & $(0.09-0.44)$ & $(0.11-0.45)$ & $(0.11-0.44)$ & $(0.08-0.41)$ & $(0.04-0.35)$ \\
Standard Error & 0.0870 & 0.0866 & 0.0854 & 0.0841 & 0.0798 \\
Observations & 180 & 180 & 180 & 180 & 180 \\
\hline \hline
\end{tabular}

\section{Basic Specification}

Source: own calculations

Level of Significance: *** $1 \% * * 5 \% * 10 \%$

${ }^{1}$ see Table 10 in the Appendix for the detailed results

2 average of father's logarithmized adjusted real gross monthly earnings

Table 4 and 5 report the general pattern that $\hat{\beta}_{y}^{O L S}$ increases with the number of years averaged as the attenuation bias declines. This is in line with equation (6). For inclusion in the balanced panel, father earnings need to be observed for 5 years in a row even though only lower averages are used for the supplementary estimations. The changing estimate is due to the reduced number of years averaged and not to a change in the sample composition. For this reason, the number of observations remains constant. The unbalanced panel, however, includes all pairs with the necessary number of successive earnings observations for the father that is needed for the respective estimation. A comparison of the OLS results in the balanced and unbalanced panel reveals that the difference between a 5 - and 4-year 
average of father's earnings is negligible. However, it makes a difference in our sample whether the estimate is based on a 1/2-year average compared to an 4/5year average. Averaging only a small number of years amplifies the attenuation bias due to a high volatility of the earnings measure utilized. This result is in line with the literature as reported in section 2.

Table 5: Summary Results ${ }^{1}$ : Unbalanced Panel

\begin{tabular}{|l|l|l|l|l|l|}
\hline \hline Father Measure $^{2}$ & \multicolumn{1}{|c|}{5 - Year } & 4 - Year & 3 - Year & 2 - Year & 1 - Year \\
\hline Intergenerational Elasticity & $0.2822^{* * *}$ & $0.2867^{* * *}$ & $0.2596^{* * *}$ & $0.2076^{* * *}$ & $0.2045^{* * *}$ \\
$95 \%$ Confidence Interval & $(0.11-0.45)$ & $(0.13-0.45)$ & $(0.10-0.41)$ & $(0.07-0.34)$ & $(0.08-0.32)$ \\
Standard Error & 0.0870 & 0.0815 & 0.0790 & 0.0695 & 0.0614 \\
Observations & 180 & 190 & 217 & 227 & 249 \\
\hline \hline
\end{tabular}

Basic Specification

Source: own calculations

Level of Significance: *** $1 \% * * 5 \% * 10 \%$

${ }^{1}$ see Table 11 in the Appendix for the detailed results

2 average of father's logarithmized adjusted real gross monthly earnings

The rather early decrease of the estimated coefficient in the unbalanced panel might be attributable to the construction of the panel. When lowering the number of years averaged, the added individuals do not report earnings in the following year likely due to un- or part-time employment. This implies that father-son pairs with larger transitory fluctuations are consecutively added to the panel.

\subsection{Investigating the Bias from Lifecycle Variation}

Raising the upper age-limit from 50 to 55 years results in a rather sharp increase in sample size and a slight decrease in estimated intergenerational persistence. However, table 6 reveals an increase in the estimate when continuing to soften the age restriction. This seems to be in line with Vogel (2007), whose estimate of intergenerational persistence in Germany based including individuals aged above 50 is slightly higher. We offer 2 explanations. First, the increase could point at sample selection with only pairs added that exhibit a particular strong persistence of earnings. But a comparison of the descriptive statistics (years of education, monthly earnings) did not offer any evidence on the type of selection. Second, the increase in the estimated level of mobility could be explained by an increase in the reliability ratio $\theta_{h}$ in our 
sample rather than a decrease as documented for the United States, figure 2, This is presumably the result of the comparatively high degree of centralization governing wage determination in Germany and employment protection laws which, together with the accumulation of specific human capital, favor incumbent workers ${ }^{12}$. This could decrease the transitory fluctuations among older German workers.

Table 6: Summary Results ${ }^{1}$ : Relaxing Age - Restrictions for Fathers

\begin{tabular}{|l|l|l|l|c|}
\hline \hline Father's Maximal Age & \multicolumn{1}{|c|}{50} & 55 & 60 & 65 \\
\hline Intergenerational Elasticity & $0.2822^{* * *}$ & $0.2509^{* * *}$ & $0.3538^{* * *}$ & $0.3584^{* * *}$ \\
$95 \%$ Confidence Interval & $(0.11-0.45)$ & $(0.10-0.41)$ & $(0.22-0.49)$ & $(0.22-0.49)$ \\
Standard Error & 0.0870 & 0.0794 & 0.0696 & 0.0686 \\
Observations & 180 & 240 & 281 & 285 \\
\hline \hline
\end{tabular}

\section{Basic Specification}

Source: own calculations

Level of Significance: *** $1 \% * * 5 \% * 10 \%$

${ }^{1}$ see Table 13 in the Appendix for the detailed results

${ }^{2} 5$-year average of father's logarithmized adjusted real gross monthly earnings; son at least 30 years of age

Table 7 documents a significant rise in the number of observations and a sharp decline in the estimated intergenerational elasticity when the age requirement for sons is consecutively lowered to 20 years. This seems to be in line with Haider \& Solon (2006). The parameter $\lambda_{t}$ (see equation (14) in section 2) is lowered as younger and younger workers are added to the sample and the lifecycle bias rises.

\footnotetext{
${ }^{12}$ See Botero, Djankov, Porta \& Lopez-De-Silanes (2004) and Franz \& Pfeiffer (2006) among others.
} 
Table 7: Summary Results ${ }^{1}$ : Relaxing Age - Restrictions for Sons

\begin{tabular}{|c|c|c|c|}
\hline Son's Minimum Age & 30 & 25 & 20 \\
\hline Intergenerational Elasticity $^{2}$ & $0.2822^{* * *}$ & $0.2553^{* * *}$ & $0.2402^{* * *}$ \\
\hline 95\% Confidence Interval & $(0.11-0.45)$ & $(0.12-0.39)$ & $(0.13-0.30)$ \\
\hline Standard Error & 0.0870 & 0.0666 & 0.0558 \\
\hline Observations & 180 & 282 & 385 \\
\hline \multicolumn{4}{|l|}{ Basic Specification } \\
\hline \multicolumn{4}{|l|}{ Source: own calculations } \\
\hline \multicolumn{4}{|c|}{ Level of Significance: *** $1 \% * * 5 \% * 10 \%$} \\
\hline \multicolumn{4}{|c|}{${ }^{1}$ see Table 14 in the Appendix for the detailed results } \\
\hline \multicolumn{4}{|c|}{$\begin{array}{l}25 \text {-year average of father's logarithmized adjusted real gross monthly earn- } \\
\text { ings; father at most } 50 \text { years of age }\end{array}$} \\
\hline
\end{tabular}

The analysis above gave the impression that the age-composition of either sample is changed without affecting the other. Obviously, this is not true since fatherson pairs are added. However, negligible changes in the age composition of the unchanged (with respect to the age restrictions imposed) sample support this approach.

\subsection{Further Sensitivity Checks}

\section{Including Younger Siblings}

The inclusion of younger siblings raises the sample size from 180 to 224 when relying on a 5-year average of father's earnings. The point estimate is slightly reduced to $\hat{\beta}_{y}^{O L S}=0.276$. Siblings share the same family and community background which makes similar long-run economic status more likely and increases homogeneity within the sample. This depresses the estimated coefficient slightly, see table 15 in the Appendix for the detailed results.

\section{Adjustment of Monthly Earnings}

To ensure robustness with respect to the measure of comparability (GDP-Growth in the baseline estimation), earnings are deflated by the growth rate of average real gross monthly earnings in Germany's industry sector (as reported by the German 
Federal Statistical Office). The estimated intergenerational elasticity is not affected, see table 16 in the Appendix for the detailed results.

\section{Instrumenting Parental Status}

To compare our findings with Wiegand (1997), the IV estimation is repeated instrumenting parental status using the Wegener-Index, a standard index for occupational prestige. The baseline estimate $\left(\hat{\beta}_{y}^{I V}=0.372\right)$ remains unchanged. The finding that both instruments lead to rather identical results is robust to changes in the sampling rule, see table 17 in the Appendix for the detailed results.

\section{Discussion and Concluding Remarks}

Figure 8 compares our result to the international evidence. Although the studies differ with respect to data and methods, the comparison suggests higher mobility (that is less persistence) in Germany compared to the United States and the United Kingdom, but lower mobility compared to Sweden. Our preferred point estimate of the elasticity in Germany is $\beta_{y}^{G E R}=\frac{1}{3}$, compared with $\beta_{y}^{U S}=0.4$ for the United States and $\beta_{y}^{S}=0.2$ for Sweden. In comparison to former studies by Couch \& Dunn (1997) and Wiegand (1997) on intergenerational persistence in Germany, Vogel (2007) and our results suggest higher persistence. This is the result of our special attention on the sources of potential lifecycle bias. However, common to all studies presented in table 8 are the considerable confidence intervals, which currently forbid any strong comparative statements on the level of intergenerational persistence. 
Table 8: International Perspective

\begin{tabular}{|l|l|l|}
\hline \hline Country & OLS Result & IV Result \\
\hline United States & $0.613(0.09)^{\mathrm{a}}$ & - \\
Mazumder (2005) & $0.413(0.09)$ & $0.526(0.14)$ \\
Solon (1992) & $0.400(0.06)$ & $0.330(0.27)$ \\
Zimmerman (1992) & & \\
United Kingdom & $0.240(0.03)$ & $0.443(0.03)$ \\
Dearden, Machin \& Reed (1997) & & \\
Sweden & $0.216(0.04)$ & - \\
Björklund \& Jäntti (1997) & $0.124(0.07)$ & - \\
Germany & $0.238(0.06)$ & $0.402(0.13)$ \\
Couch \& Dunn (1997) & $0.266(0.06)$ & - \\
Wiegand (1997) & $0.282(0.09)$ & $0.374(0.14)$ \\
\hline Vogel (2007) & \\
this volume &
\end{tabular}

a Standard errors in parentheses.

For illustrative reasons, we conclude by figuring out some consequences of the value of $\beta_{y}^{G E R}=\frac{1}{3}$ for Germany. The intergenerational elasticity $\beta_{y}$ translates intragenerational inequality in parental long-run labor market status into the economic advantage, which a child from parents with higher economic status can hope for compared to one from lower status parents. Table 9 depicts the advantage of a child with parents in the top permanent earnings decile compared to offspring born to parents in the bottom decile as determined by equation (23) (Corak 2004).

$$
\frac{y_{1}^{90 t h}}{y_{1}^{10 t h}}=\left(\frac{y_{0}^{90 t h}}{y_{0}^{10 t h}}\right)^{\beta_{y}}
$$


Table 9: Inequality and the Expected Permanent Earnings Advantage

\begin{tabular}{|l|c|c|c|c|}
\hline \hline & \multicolumn{4}{|c|}{ Intergenerational Elasticity } \\
$90 / 10$ - Ratio & 0.2 & $\frac{1}{3}$ & 0.4 & 0.5 \\
\hline 2.0 & $15 \%$ & $25 \%$ & $32 \%$ & $41 \%$ \\
2.5 & $20 \%$ & $35 \%$ & $44 \%$ & $58 \%$ \\
3.0 & $25 \%$ & $44 \%$ & $55 \%$ & $73 \%$ \\
3.5 & $28 \%$ & $51 \%$ & $65 \%$ & $87 \%$ \\
4.0 & $32 \%$ & $59 \%$ & $74 \%$ & $100 \%$ \\
\hline \hline
\end{tabular}

For Germany, Gernandt \& Pfeiffer (2007) calculate a 90/10-percentile earnings ratio of 2.5 for a cross-section sample of prime age dependent male workers in 2005, which is rather close to our one. Then, taking our advocated value for an intergenerational elasticity in Germany of $\beta_{y}^{G E R}=\frac{1}{3}$, the expected earnings advantage amounts to $35 \%$. If $\beta_{y}^{G E R}$ would be 0.5 , the advantage increases to $59 \%$.

Summarizing our findings, we find intergenerational earnings persistence among West German workers is higher than previously suggested. A value of $\beta_{y}^{G E R}=\frac{1}{3}$ still indicates that there is substantial intergenerational mobility, which presumably is one result of the massive expansion of publicly funded education in Germany from the seventies. 


\section{References}

Albarrán, Pedro, Raquel Carrasco and Maite Martínez-Granado. 2007. "Inequality for Wage Earners and Self-Employed: Evidence from Panel Data." Universidad Carlos III de Madrid Economic Working Paper 24.

Baker, Michael. 1997. "Growth-Rate Heterogeneity and the Covariance-Structure of Life-Cycle Earnings." Journal of Labor Economics 15(2):338-375.

Baker, Michael and Gary Solon. 2003. "Earnings Dynamics and Inequality Among Canadian Men 1976-1992." Journal of Labor Economics 21(2):267-288.

Becker, Gary S. and Nigel Tomes. 1986. "Human Capital and the Rise and Fall of Families." Journal of Labor Economics 4(3):1-39.

Behrman, Jere and Paul Taubman. 1985. "Intergenerational Earnings Mobility in the United States: Some Estimates and a Test of Becker's Intergenerational Endowments Model." The Review of Economics and Statistics 67(1):144-151.

Björklund, Anders. 1993. "A Comparison Between Actual Distributions of Annual and Lifetime Income: Sweden 1951-89." Review of Income and Wealth $39(4): 377-386$.

Björklund, Anders and Markus Jäntti. 1997. "Intergenerational Income Mobility in Sweden Compared to the United States." The American Economic Review 87(5):1009-1018.

Blau, Francine D. and Lawrence M. Kahn. 1996. "International Differences in Male Wage Inequality: Institutions versus Market Forces." Journal of Political Economy 104(4):791-837.

Borjas, George. 2006. "Making it in America: Social Mobility in the Immigrant Population." NBER Working Paper Series 12088.

Botero, Juan, Simeon Djankov, Rafael Porta and Florencio Lopez-De-Silanes. 2004. "The Regulation of Labor." The Quarterly Journal of Economics 119(4):13391382 .

Bound, John and Alan B. Krueger. 1991. "The Extent of Measurement Error in Longitudinal Earnings Data: Do Two Wrongs Make a Right?" Journal of Labor Economics 9(1):1-24. 
Bowles, Samuel. 1972. "Schooling and Inequality from Generation to Generation." The Journal of Political Economy 80(3):219-251.

Bowles, Samuel and Herbert Gintis. 2002. "The Inheritance of Inequality." The Journal of Economic Perspectives 16(3):3-30.

Bowles, Samuel, Herbert Gintis and Melissa Osborne-Groves. 2001. "The Determinants of Earnings: A Behavioral Approach." Journal of Economic Literature 39(4):1137-1176.

Card, David. 1994. Intertemporal Labor Supply: An Assessment. In Advances in Econometrics Sixth World Congress, ed. Christopher A. Sims. Vol. 2 Cambridge University Press pp. 49-81.

Card, David. 1999. The Casual Effect of Education on Earnings. In Handbook of Labor Economics, ed. Orley Ashenfelter and David Card. Vol. 3 North-Holland Publishing Company pp. 1801-1863.

Corak, Miles. 2004. Generational Income Mobility in North America and Europe: An Introduction. In Generational Income Mobility in North America and Europe, ed. Miles Corak. Cambridge University Press pp. 1-37.

Corcoran, Mary, Deborah Laren, Roger Gordon and Gary Solon. 1991. "A Longitudinal Analysis of Sibling Correlation in Economic Status." The Journal of Human Resources 26(3):509-534.

Couch, Kenneth A. and Thomas A. Dunn. 1997. "Intergenerational Correlation in Labor Market Status: A Comparison of the United States and Germany." The Journal of Human Resources 32(1):210-232.

Dearden, Lorraine, Steve Machin and Howard Reed. 1997. "Intergenerational Mobility in Britain." The Economic Journal 107(440):47-66.

Duncan, Greg J. and Daniel H. Hill. 1985. "An Investigation of the Extent and Consequences of Measurement Error in Labor-Economic Survey Data." Journal of Labor Economics 3(4):508-532.

Franz, Wolfgang and Friedhelm Pfeiffer. 2006. "Reasons for Wage Rigidites in Germany." Labour Economics 20(2):255-284. 
Friedberg, Rachel M. 2000. "You Can’t Take it With You? Immigrant Assimilation and the Portability of Human Capital." Journal of Labor Economics 18(2):221251.

Friedman, Milton. 1957. A Theory of the Consumption Function. Princeton, New Jersey: Princeton University Press.

Gernandt, Johannes and Friedhelm Pfeiffer. 2007. "Rising Wage Inequality in Germany." Jahrbücher für Nationalökonomie und Statistik 227(4):in print.

Goldberger, Arthur S. 1981. "Linear Regression After Selection." Journal of Econometrics 15(3):357-366.

Goldberger, Arthur S. 1989. "Economic and Mechanical Models of Intergenerational Transmission." The American Economic Review 79(3):504-513.

Grawe, Nathan D. 2006. "Lifecycle Bias in Estimates of Intergenerational Earnings Persistence." Labour Economics 13(5):551-570.

Haider, Steven J. and Gary Solon. 2006. "Life-Cycle Variation in the Association Between Current and Lifetime Earnings." The American Economic Review 96(4):1308-1320.

Haisken-DeNew, John P. and Joachim R. Frick. 2005. "Desktop Companion to the German Socio-Economic Panel (SOEP).".

Hunt, Jennifer. 2002. "The Transition in East Germany: When is a Ten-Point Fall in the Gender Wage Gap Bad News?" Journal of Labor Economics 20(1):148-169.

Hyslop, Dean. 2001. "Rising U.S. Earnings Inequality and Family Labor Supply: The Covariance Structure of Intrafamily Earnings." The American Economic Review 91(4):755-777.

Jäntti, Markus, Knut Røed, Robin Naylor, Anders Björklund, Bernt Bratsberg, Oddbjörn Raaum, Eva Österbacka and Tor Erikson. 2006. "American Exceptionalism in a New Light: A Comparison of Intergenerational Earnings Mobility in the Nordic Countries, the United Kingdom and the United States." IZA Discussion Paper 1938. 
Jenkins, Stephen. 1987. "Snapshots versus Movies: Lifecycle Biases and the Estimation of Intergenerational Earnings Inheritance." European Economic Review 31(5):1149-1158.

Mazumder, Bhashkar. 2005. "Fortunate Sons: New Estimates of Intergenerational Mobility in the United States Using Social Security Earnings Data." The Review of Economics and Statistics 87(2):235-255.

Mincer, Jacob. 1975. Schooling, Experience and Earnings. New York: National Bureau of Economic Research.

Mulligan, Casey B. 1997. Parental Priorities and Economic Inequality. Chicago: University of Chicago Press.

OECD. 1999. OECD Employment Outlook. Paris: OECD Publication Service.

Pfeiffer, Friedhelm. 1994. Selbständige und Abhängige Erwerbstätigkeit: Arbeitsmarkt- und Industrieökonomische Perspektiven. Frankfurt am Main: Campus Verlag.

Piketty, Thomas. 2000. Theories of Persistent Inequality and Intergenerational Mobility. In Handbook of Income Distribution, ed. Anthony B. Atkinson and Francois Bourguignon. Elsevier Science pp. 429-476.

Pries, Michael and Richard Rogerson. 2005. "Hiring Policies, Labor Market Institutions and Labor Market Flows." Journal of Political Economy 113(4):811-839.

Sewell, William H. and Robert M. Hauser. 1975. Education, Occupation and Earnings: Achievement in the Early Career. New York: Academic Press.

Solon, Gary. 1989. "Biases in the Estimation of Intergenerational Earnings Correlations." The Review of Economics and Statistics 71(1):172-174.

Solon, Gary. 1992. "Intergenerational Income Mobility in the United States." The American Economic Review 82(3):393-408.

Solon, Gary. 1999. Intergenerational Mobility in the Labor Market. In Handbook of Labor Economics, ed. Orley Ashenfelter and David Card. Vol. 3A NorthHolland Publishing Company pp. 1761-1800.

Solon, Gary. 2002. "Cross-Country Differences in Intergenerational Earnings Mobility." The Journal of Economic Perspectives 16(3):59-66. 
Vogel, Thorsten. 2007. "Reassessing Intergenerational Mobility in Germany and the United States: The Impact of Differences in Lifecycle Earnings Patterns." School of Business and Economics, Humboldt University of Berlin.

Wiegand, Johannes. 1997. Four Essays on Applied Welfare Measurement and Income Distribution Dynamics in Germany 1985-1995. London: University College London.

Zimmerman, David J. 1992. "Regression Toward Mediocrity in Economic Stature." The American Economic Review 82(3):409-429. 
A. Estimation Appendix 


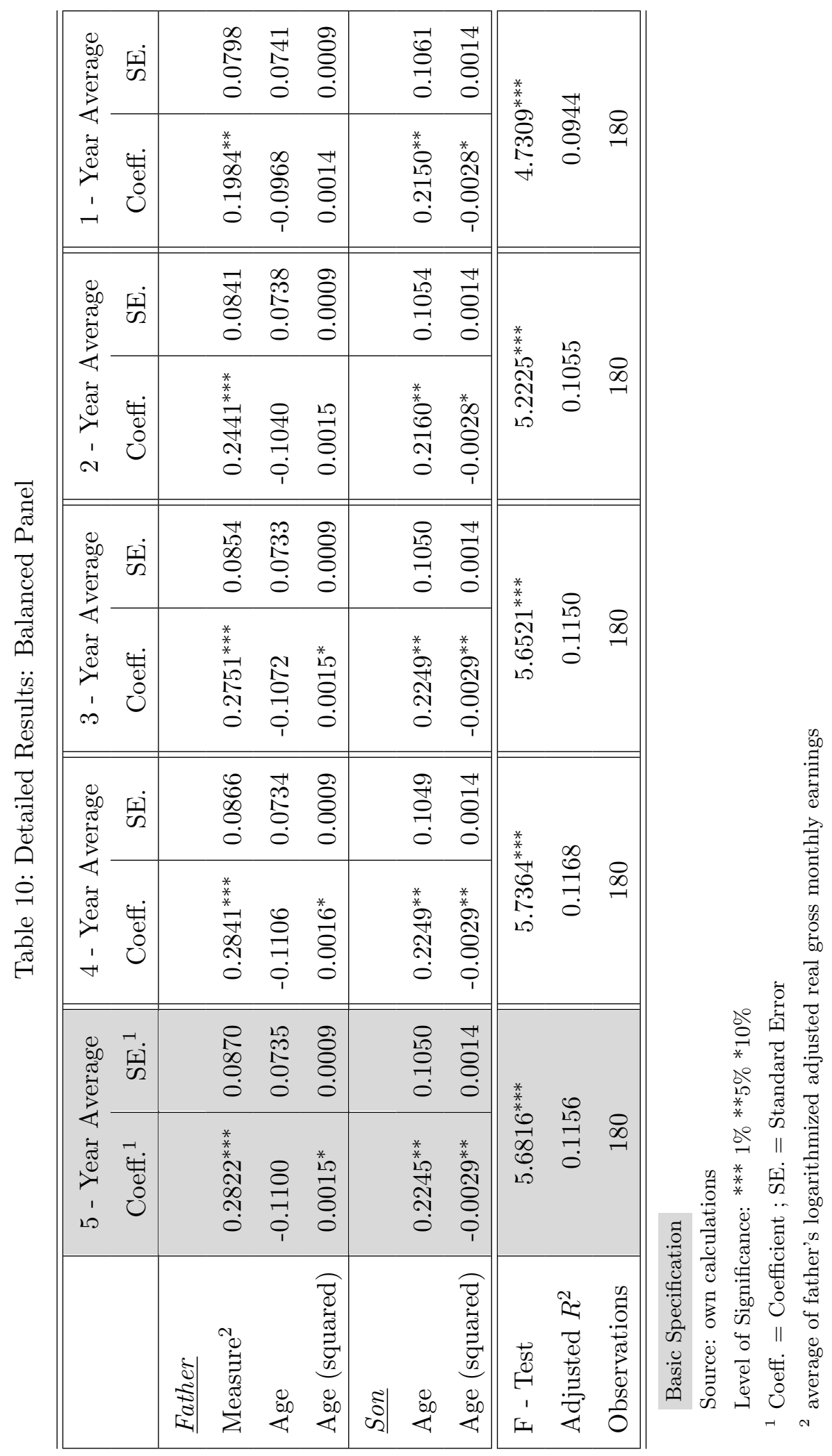




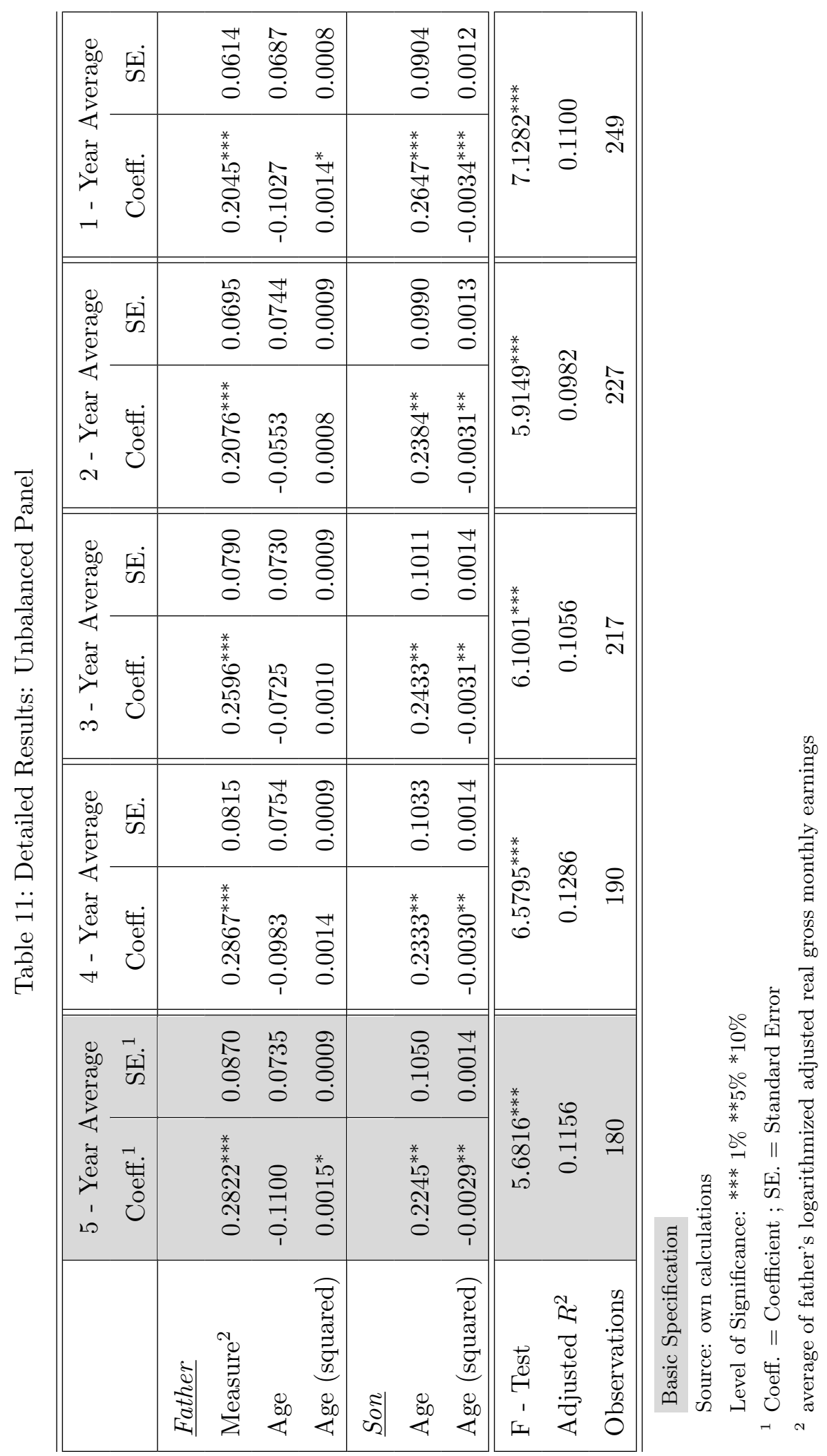




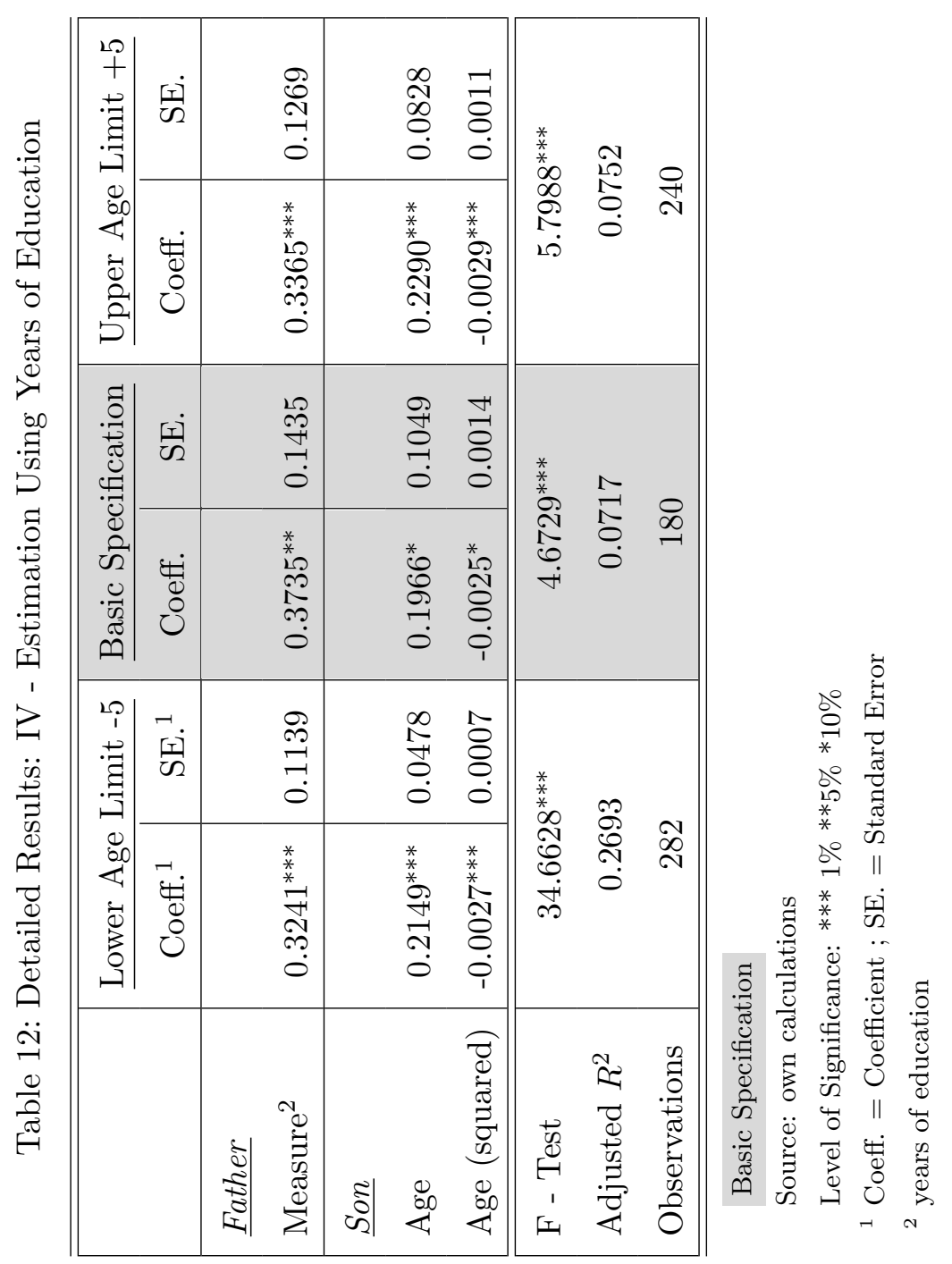




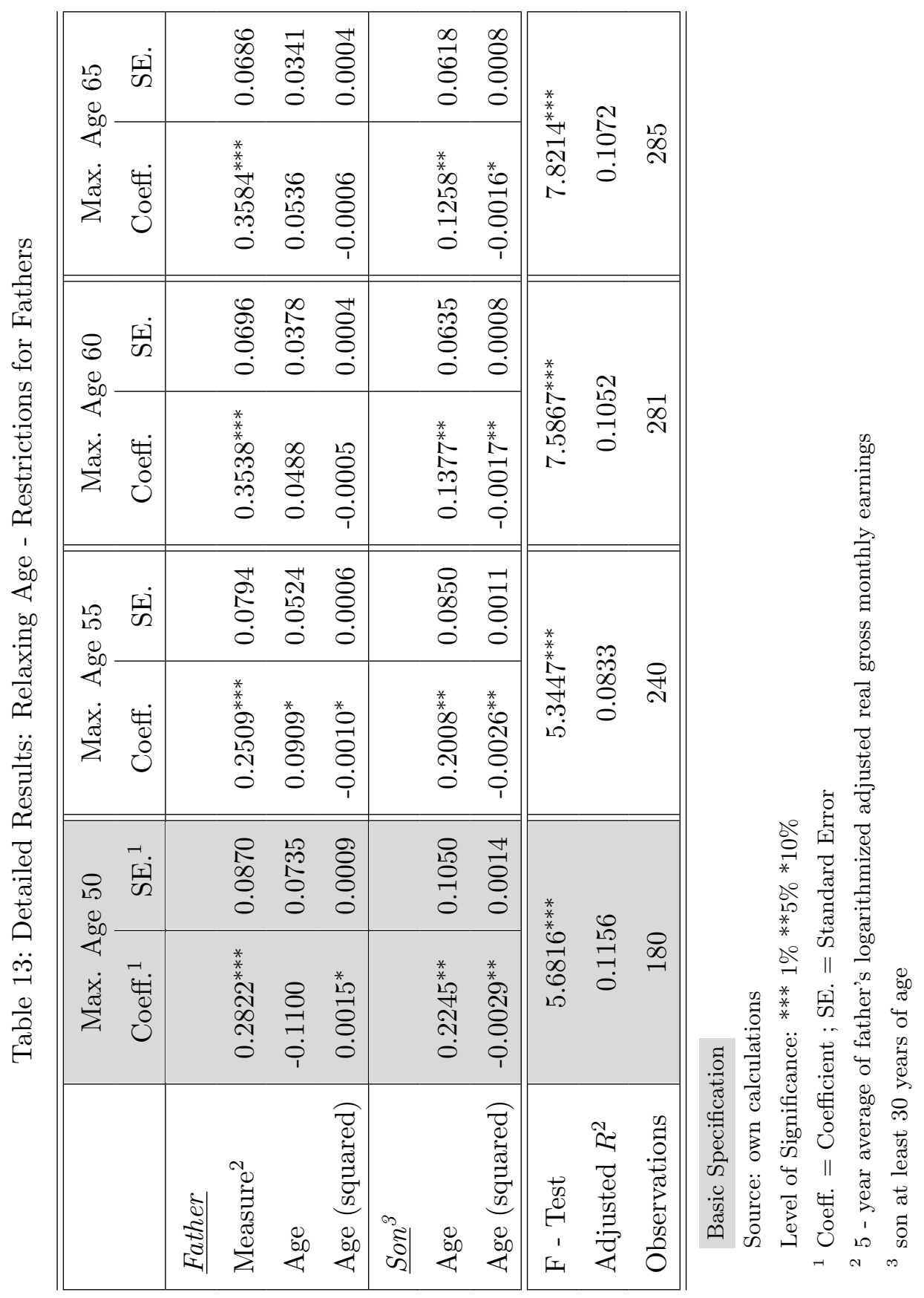




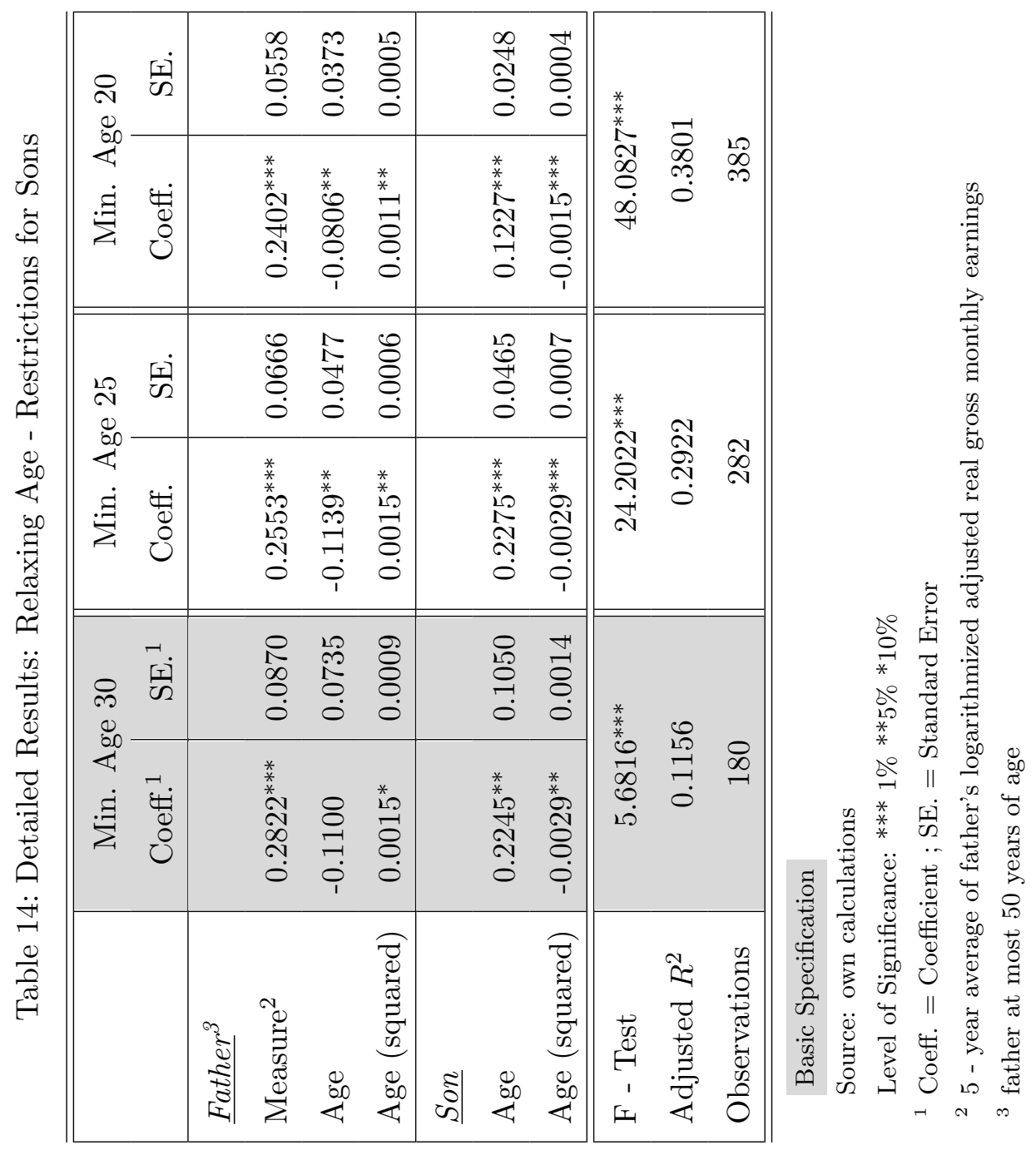




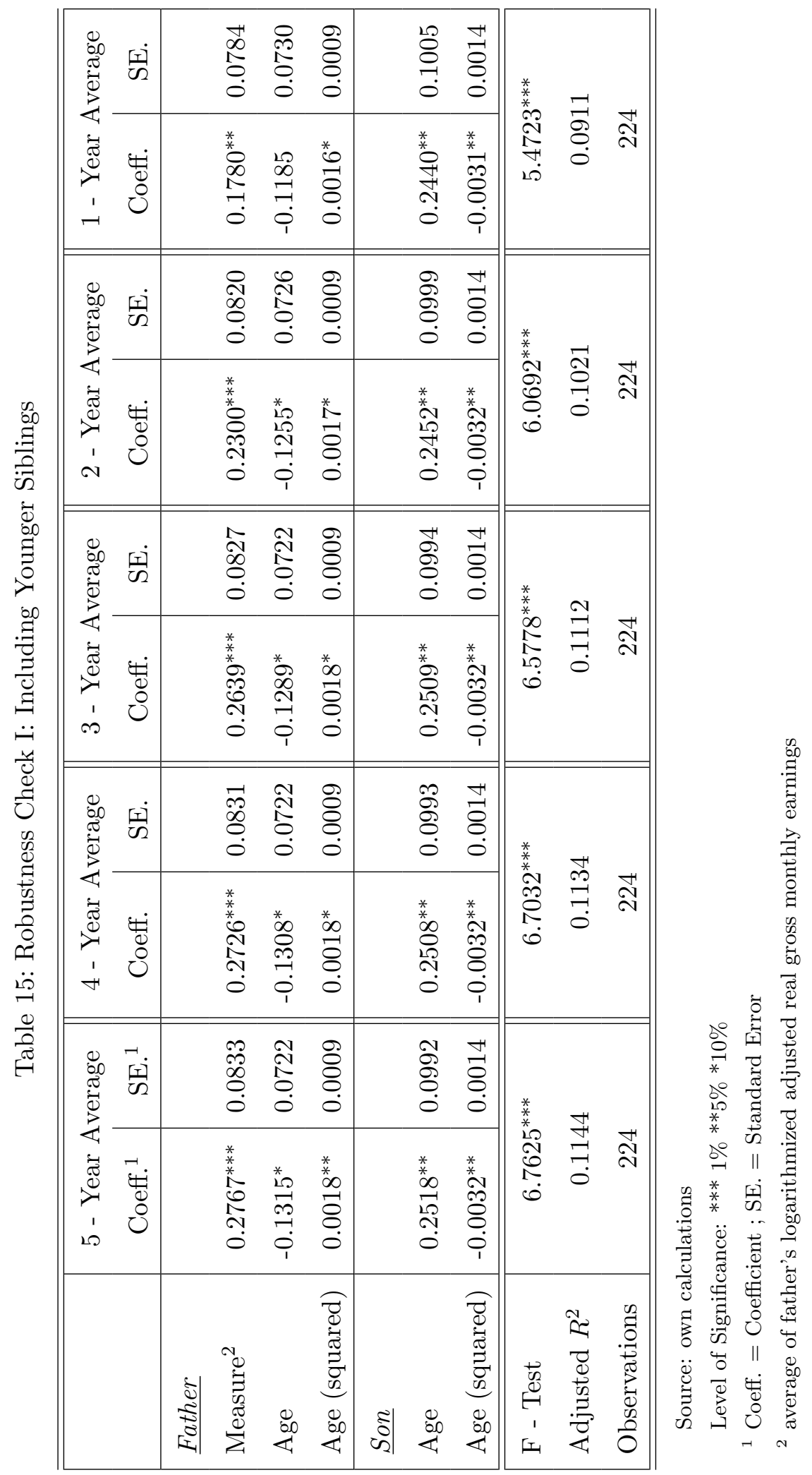




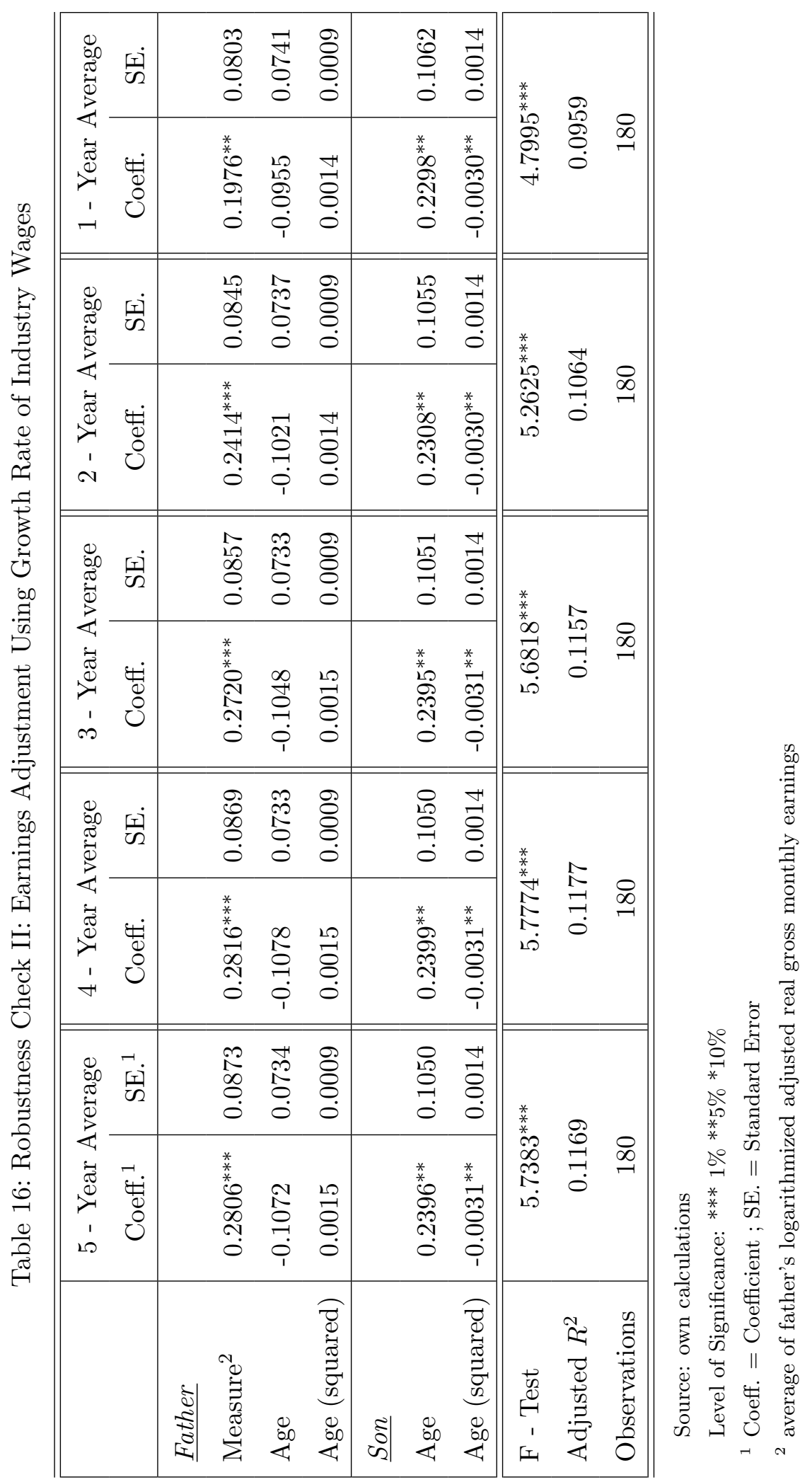




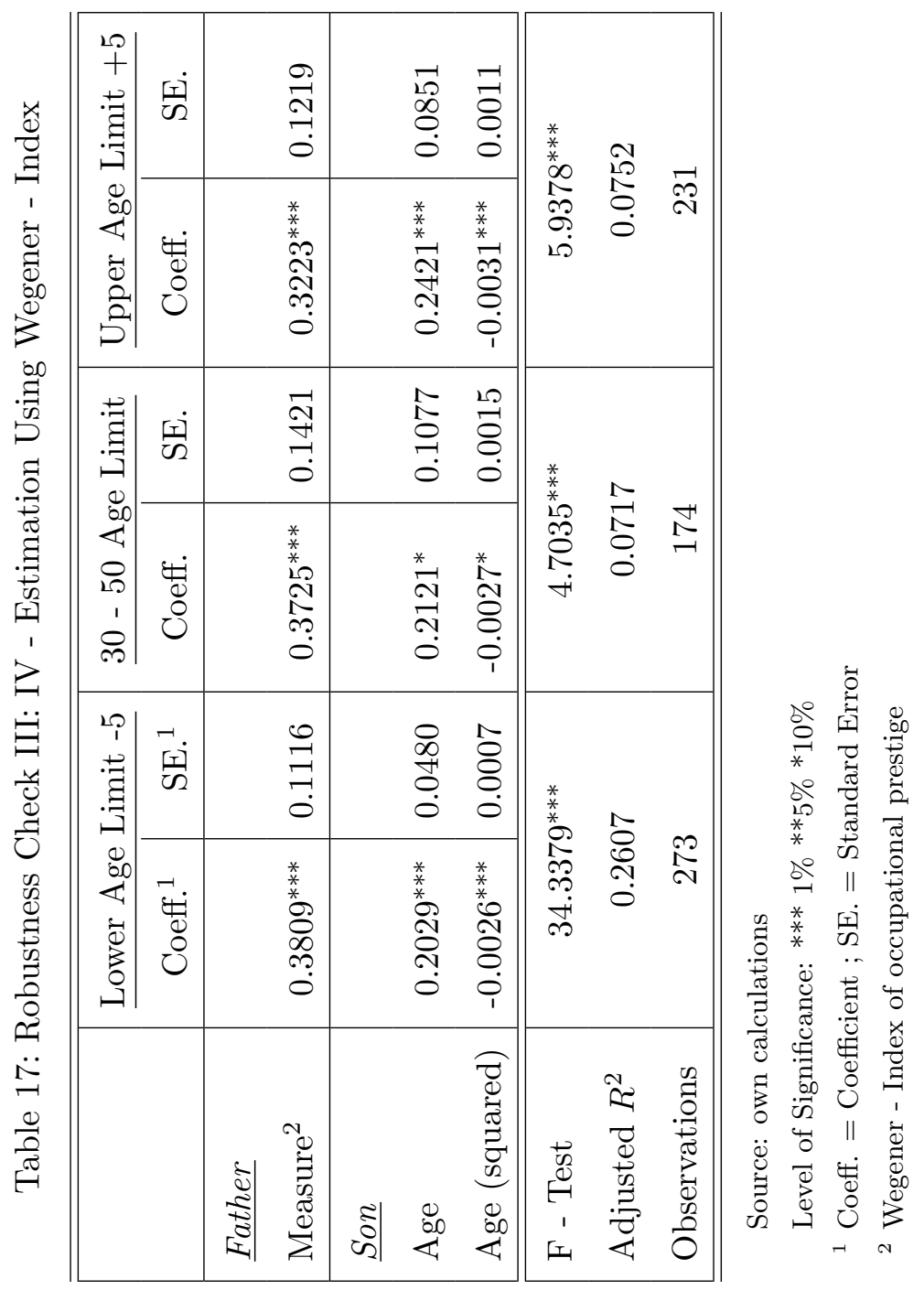

